\title{
How can guidelines help us in daily practice
}

Siegfried Kasper

\author{
From $1^{\text {st }}$ International Congress on Neurobiology and Clinical Psychopharmacology and European \\ Psychiatric Association Conference on Treatment Guidance \\ Thessaloniki, Greece. 19-22 November 2009
}

There are a number of national as well as international guidelines on the treatment of major psychiatric disorders available. The World Federation of Societies of Biological Psychiatry (WFSBP) publishes guidelines on unipolar depression, bipolar disorder, anxiety disorders, addiction, eating disorders, dementia, just to name a few of them. Whereas national guidelines can limitate themselves to the different kinds of medication that are available, a global perspective on guidelines needs to consider that there are different cultural beliefs and attitudes towards the disease, different legal and regulatory perspectives. Moreover, practice patterns change among countries and there are unique drug availabilities. Furthermore, the healthcare pay system might limitate one or the other treatment option and specific treatments might not have support from professional bodies and opinion leaders. It is noteworthy to mention that treatment guidelines should not be viewed as rigorous algorithm which should be followed in everyday practice. However, the more summaries the more information is available in the literature to guide clinicians in their everyday clinical practice.

Published: 22 April 2010

doi:10.1186/1744-859X-9-S1-S65

Cite this article as: Kasper: How can guidelines help us in daily practice. Annals of General Psychiatry 2010 9(Suppl 1):S65.
Department of Psychiatry and Psychotherapy, Medical University of Vienna, Austria
Submit your next manuscript to BioMed Central and take full advantage of:

- Convenient online submission

- Thorough peer review

- No space constraints or color figure charges

- Immediate publication on acceptance

- Inclusion in PubMed, CAS, Scopus and Google Scholar

- Research which is freely available for redistribution

Submit your manuscript at www.biomedcentral.com/submit 